\title{
Effect of Heat Treatment on Microstructure, Mechanical Properties and Erosion Behaviour of Cast 21-4-N Nitronic Steel
}

\author{
Avnish Kumar $^{1 *}$, Gaurav Tripathi ${ }^{1,2}$, Anurag Hamilton ${ }^{1}$, Ashok Sharma ${ }^{1}$ \\ ${ }^{1}$ Department of Metallurgical and Materials Engineering, Malaviya National Institute of Technology Jaipur, Rajasthan 302017, India \\ ${ }^{2}$ Department of Mechanical Engineering, Ajay Kumar Garg Engineering College Ghaziabad, Uttar Pradesh 201009, India
}

Received: May 02, 2016; Accepted: June 19, 2016; Published: July 30, 2016

*Corresponding author: Avnish Kumar, Department of Metallurgical and Materials Engineering, Malaviya National Institute of Technology Jaipur, Rajasthan 302017, India, Tel/ Fax: +91 141 2713343; E-mail: avnishmnit@gmail.com

\begin{abstract}
Microstructure and mechanical properties are closely related to the erosion behavior of the material. Modification of microstructure and mechanical properties through heat treatment can significantly enhance the erosion resistance of steel. Therefore, cast 21-4-N nitronic steel was solution treated at two different heat treatment cycle to observe the effect on microstructure, mechanical properties, and erosion behavior. The microstructures, phases and eroded surfaces were studied by optical microscopy, X-Ray Diffraction (XRD) analysis and Scanning Electron Microscopy (SEM) respectively. It has been observed that solution treatment leads to the dissolution of carbides, which improved the tensile strength, ductility, and impact energy with a minor reduction in hardness of cast 21-4-N nitronic steel. It resulted in enhancement of the erosion resistance of cast 21$4-\mathrm{N}$ nitronic steel.
\end{abstract}

Keywords: Erosion; Heat Treatment; Nitronic Steel; Microstructure; Erosion Resistance

\section{Introduction}

Erosion in underwater parts of hydroturbine by hard silt particles becomes a serious issue in hydropower plants located in Himalayan region of India. Severe damages are reported in hydroturbine components due to silt erosion which leads to decrease in the efficiency of the power plant [1-3]. Therefore, it is necessary to pay special attention towards the development of better erosion resistant materials. Presently, 13/4 martensitic stainless steel (CA6NM) is being used as turbine blade material. However, this steel is severely affected by prolonged exposure to slurry erosion and also possesses poor weldability [4]. Extensive study has been carried out in the past to identify the factors responsible for severe erosive damages in hydroturbine components due to attack from silt-laden water. These factors can be broadly classified as impingement variables, erosive particle variables, and metallurgical variables. Due to practical limitations, it is possible only to regulate the metallurgical factors effectively. These metallurgical factors mainly include the microstructure and the mechanical properties of the material [2].
Nitronic steel is emerging as an alternative material to currently used martensitic stainless steel [3, 5-7] for hydroturbine applications. Nitronic steels are basically austenitic stainless steel containing nitrogen as an alloying element in the matrix. Nitrogen in austenitic stainless steels improves the strength, ductility, toughness, work hardening capacity, and resistance to erosion and corrosion [8, 9]. The initial structure of cast nitronic steels is usually a heterogeneous mixture of austenite and massive precipitates of carbides. Previous studies [10-12] showed that volume fraction, size, morphology, orientation and distribution of carbides affect the erosion resistance of material. Hard and disperse second phases in the microstructure can accelerate the hard particle release from the surface during the erosion and increase the total mass loss. Thus, appropriate solution treatment at high temperatures can play a major role in obtaining structures free from carbides for improving erosion resistance. Kim et al. [13] observed that heat treatment increased the cavitation resistance due to morphological change of carbide in 316 and 304 steel. Salik and Buckley [14] concluded that heat treatment and the resulting microstructure of plain carbon steel have an intense effect on the resistance to erosion.

In the present investigation, an attempt is made systematically to investigate the changes in the microstructure, mechanical properties and erosion behaviour of cast 21-4-N nitronic steel under different solution treatment condition.

\section{Experimental Procedure}

The cast 21-4-N nitronic steel was selected for present investigation. A rectangular bar of $40 \mathrm{~mm} \times 40 \mathrm{~mm}$ crosssection was received from M/s Star Wire (India) Ltd., Ballabgarh (Haryana). The chemical composition of the 21-4-N nitronic steel is shown in Table 1. Specimens for metallographic examination, tensile, impact and erosion tests were prepared from this bar. In order to investigate the effect of heat treatment on microstructure, cubical specimens of $20 \mathrm{~mm}$ were solution treated at $1030^{\circ} \mathrm{C}$ and $1080^{\circ} \mathrm{C}$ for the holding time of $150 \mathrm{~min}$. The specimens were then water quenched at room temperature to prevent the precipitation 
Table 1: Chemical composition of 21-4-N nitronic steel (wt. \%).

\begin{tabular}{|c|c|c|c|c|c|c|c|c|c|c|c|c|c|}
\hline Steel & C & Cr & Ni & Mn & N & Si & Mo & S & P & 0.18 & 0.13 & 0.001 & 0.044 \\
\hline $21-4-N$ Steel & 0.53 & 20.82 & 3.66 & 8.76 & 0.45 & Bal. \\
\hline
\end{tabular}

of carbides. After that, cast and solution treated specimens were ground and polished as per standard metallographic practice and etched with aquaragia $\left(3: 1-\mathrm{HCl}: \mathrm{HNO}_{3}\right)$. Etched samples were examined under Carl Zeiss Axiovert 200 MAT inverted optical microscope at different magnifications. The presence of phases in cast and solution treated samples was identified by X-ray diffractometer (XRD, D8- Bruker AXS, Germany with $\mathrm{Cu} \mathrm{K \alpha}$ radiation). The Vickers hardness measurements were carried out using Matsuzawa hardness testing machine (Model No. DMN1). A load of $30 \mathrm{kgf}$ was applied to the specimen for $10 \mathrm{sec}$ for measuring the hardness. Tensile test measurements were carried using the Tinus Olsen tensometer testing machine. Standard tensile specimens with gauge length $20 \mathrm{~mm}$ and gauge diameter 4 mm were prepared as per ASTM E8M-08 to determine the values of Ultimate Tensile Strength (UTS) and ductility (\% elongation). Standard Charpy V-notch impact specimens of dimension 10 $\mathrm{mm} \times 10 \mathrm{~mm} \times 55 \mathrm{~mm}$ were prepared as per ASTM E23-07 specification and the tests were performed at room temperature. The above results reflect the average value of five samples. Slurry erosion test was performed using slurry pot tester as shown in Figure 1. The erosion testing parameters are given in Table 2. The morphology of silica sand particle used in testing is shown in Figure 2. Two similar T headed specimens were inserted into the rectangular slots of the sample holding disc and tested for 24 hours. The weight loss of samples was measured after threehour interval in electronic balance having least count of $0.01 \mathrm{mg}$.

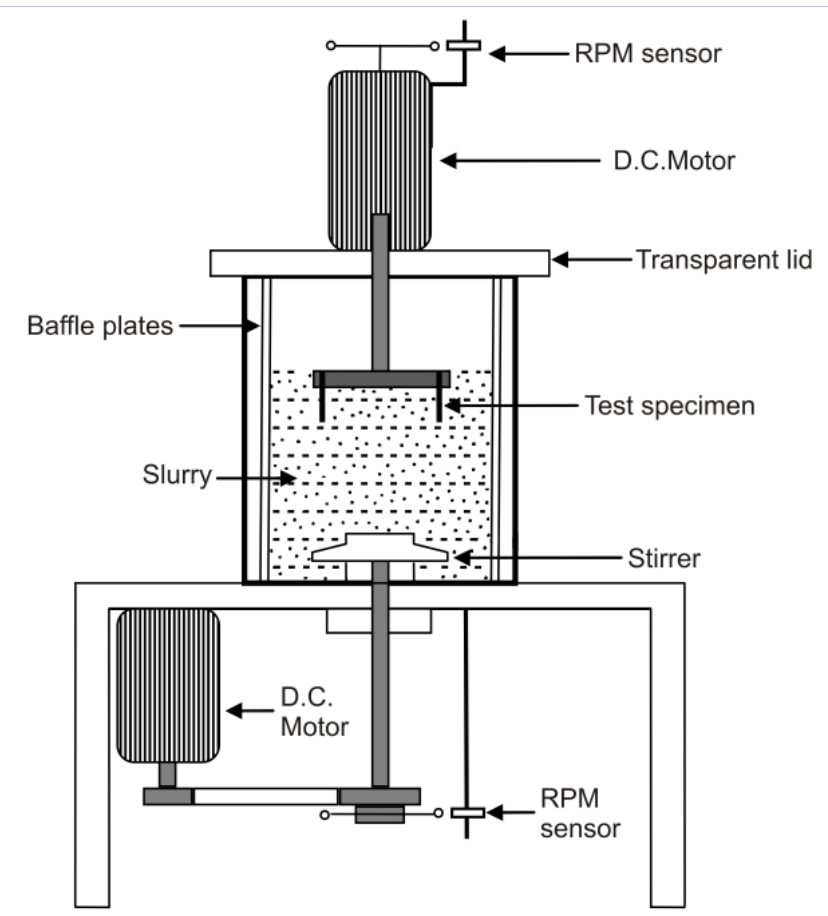

Figure 1: Schematic view of slurry pot tester.

\begin{tabular}{|l|l|}
\hline \multicolumn{2}{|l|}{ Table 2: Parameters used in slurry erosion testing. } \\
\hline Sand Particle & Silica \\
\hline Specific gravity of sand particle & 2.55 \\
\hline Sand concentration in water & $15 \%$ sand in 17-liter water \\
\hline Average size of sand particle & $525 \mu \mathrm{m}$ \\
\hline Stirrer speed & $1100 \mathrm{rpm}$ \\
\hline Sample speed & $140 \mathrm{rpm}$ \\
\hline Sample size & $(55 \times 20 \mathrm{x} 3) \mathrm{mm}^{3}$ \\
\hline
\end{tabular}

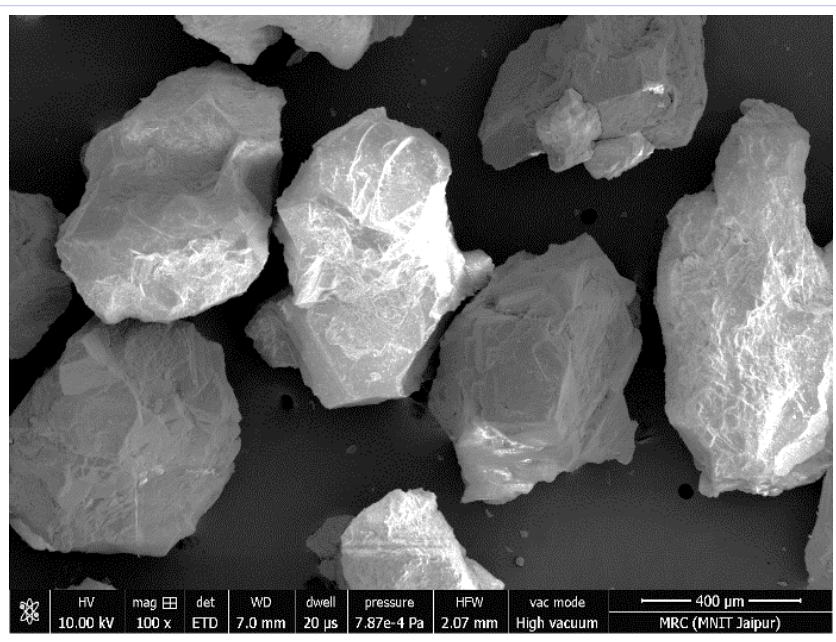

Figure 2: Morphology of silica sand particles used in slurry erosion test.

The eroded samples were examined under the scanning electron microscope (FEI Netherlands, Quanta 2000).

\section{Results and Discussions}

\section{XRD Analysis}

Figure 3 shows the X-ray diffraction patterns of the cast and solution treated $21-4-\mathrm{N}$ nitronic steel at $1030^{\circ} \mathrm{C}$ and $1080^{\circ} \mathrm{C}$ for $150 \mathrm{~min}$. The diffraction pattern of the cast 21-4-N nitronic steel showed austenite $(\gamma)$ as major peak, which is overlapped with carbides peaks. It is confirmed from the JCPDF data that $\mathrm{Cr}_{7} \mathrm{C}_{3}$ and $\mathrm{Cr}_{23} \mathrm{C}_{6}$ carbides were the main precipitates. It is clearly visible from the XRD plot that the peak of carbides is much higher in cast condition than in solution treated condition. After the solution treatment at $1030^{\circ} \mathrm{C}$ and $1080^{\circ} \mathrm{C}$ for $150 \mathrm{~min}$, carbides peaks drastically decrease due to the dissolution of carbides in austenite matrix. The relative intensity of the carbides peaks decreases as increasing the solution treatment temperature. Higher solution treatment temperature $\left(1080^{\circ} \mathrm{C}\right)$ dissolved the most of the carbides and resulted in an increase in volume fraction of the austenite phase. Therefore, austenite peaks become sharper and more intense. 


\section{Microstructure}

The optical microstructure of cast 21-4-N nitronic steel is shown in Figure $4(\mathrm{a}, \mathrm{b})$. It possesses predominantly austenitic matrix (bright phase) along with the precipitates of carbides (dark phase). The $\mathrm{M}_{7} \mathrm{C}_{3}$ (where $\mathrm{M}=\mathrm{Cr}$ ) carbide was found as the main precipitate in cast 21-4-N nitronic steel due to a higher concentration of $\mathrm{N}$ and $\mathrm{C}$ and also high $\mathrm{C}$ : $\mathrm{Cr}$ ratio [3-5]. This type of carbide forms a continuous network of lamellar morphology [3]. Higher magnification microstructure shows the lamellar morphology of $\mathrm{M}_{7} \mathrm{C}_{3}$ carbide (Figure 4 (b)). $\mathrm{M}_{23} \mathrm{C}_{6}$ carbide was also observed to precipitate at the grain boundary because it is the most favorable place for such types of carbide.

Figure $5(\mathrm{a}, \mathrm{b})$ shows the microstructure after solution treatment at $1030^{\circ} \mathrm{C}$ for $150 \mathrm{~min}$. It was observed that volume fraction of the carbides decreases significantly as compared to cast structure due to its part dissolution into the matrix. The reduction in the volume fraction of carbide is attributed to diffusion of chromium and carbon elements into the matrix after gaining required energy. When the temperature was further increased to $1080^{\circ} \mathrm{C}$ dissolution of carbides in the austenitic matrix becomes more uniform. It can be clearly observed from the microstructures as shown in Figure $6(\mathrm{a}, \mathrm{b})$. Solution treated $\left(1080^{\circ} \mathrm{C} / 150 \mathrm{~min}\right) 21-4-\mathrm{N}$ nitronic steel exhibits a better dispersion of carbides in the austenitic matrix than cast structure.

\section{Mechanical Properties}

Table 3 shows the mechanical properties of cast and solution treated $21-4-\mathrm{N}$ nitronic steel at $1030^{\circ} \mathrm{C}$ and $1080^{\circ} \mathrm{C}$ for $150 \mathrm{~min}$ Cast 21-4-N nitronic steel exhibits higher hardness than both solution treated 21-4-N nitronic steel, which could be attributed to precipitation of chromium carbides. It is evident from tensile results that the Ultimate Tensile Strength (UTS) and ductility of solution annealed 21-4-N nitronic steel is better than that of cast 21-4-N nitronic steel. Impact strength was found to improve considerably after the solution treatment of steel. It is due to the dissolution of carbides, which enriched the austenite phase and

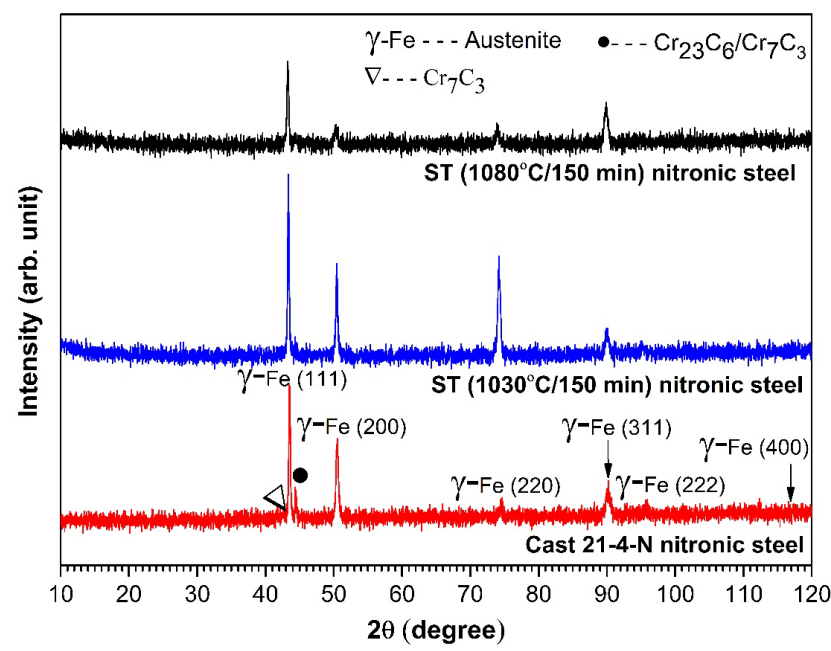

Figure 3: X-ray diffraction pattern of cast and solution treated 21-4-N nitronic steel at $\left(1030^{\circ} \mathrm{C} / 150 \mathrm{~min}\right)$ and $\left(1080^{\circ} \mathrm{C} / 150 \mathrm{~min}\right)$.
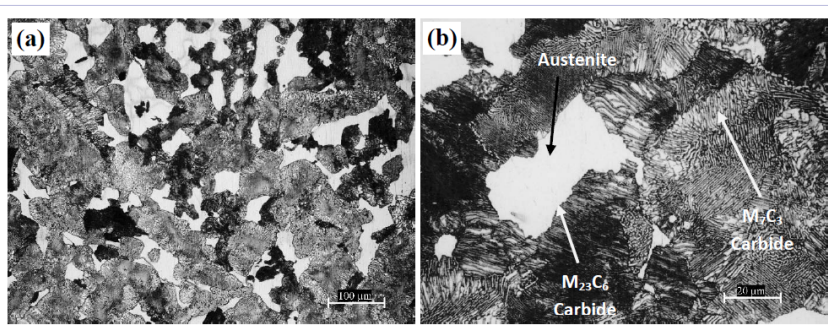

Figure 4: Optical microstructure of cast 21-4-N nitronic steel: (a) lower magnification; (b) higher magnification. (a)

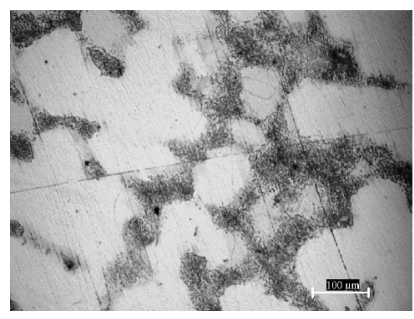

(b)

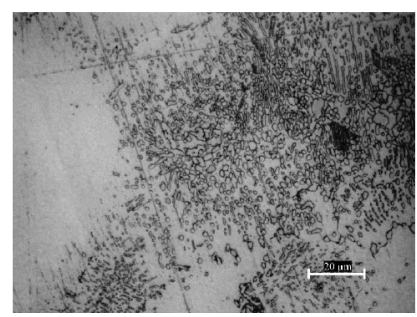

Figure 5: Optical microstructure of solution treated 21-4-N nitronic steel at $1030^{\circ} \mathrm{C}$ for 150 min: (a) lower magnification; (b) higher magnification.
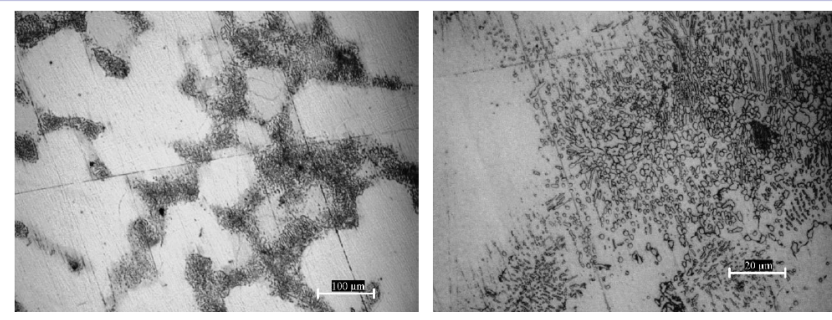

Figure 6: Optical microstructure of solution treated 21-4-N nitronic steel at $1080^{\circ} \mathrm{C}$ for 150 min: (a) lower magnification; (b) higher magnification.

Table 3: Mechanical properties of cast and solution treated (ST) 21-4-N nitronic steel at $\left(1030^{\circ} \mathrm{C} / 150 \mathrm{~min}\right)$ and $\left(1080^{\circ} \mathrm{C} / 150 \mathrm{~min}\right)$.

\begin{tabular}{|l|c|c|c|c|}
\hline Steel & Hardness & $\begin{array}{l}\text { U.T.S. } \\
\text { (MPa) }\end{array}$ & $\begin{array}{l}\text { Ductility } \\
\text { (\%Elonga- } \\
\text { tion) }\end{array}$ & $\begin{array}{l}\text { Impact } \\
\text { energy } \\
\text { (J) }\end{array}$ \\
\hline Cast 21-4-N nitronic steel & 343 & 810 & 14 & 08 \\
\hline $\begin{array}{l}\text { ST }\left(1030^{\circ} \mathrm{C} / 150 \text { min) } 21-\right. \\
4-N \text { nitronic steel }\end{array}$ & 311 & 852 & 25 & 17 \\
\hline $\begin{array}{l}\text { ST }\left(1080^{\circ} \mathrm{C} / 150 \text { min) } 21-\right. \\
4-N \text { nitronic steel }\end{array}$ & 292 & 894 & 37 & 39 \\
\hline
\end{tabular}

austenite has the tendency of good ductility, strength and impact energy.

\section{Erosion Behavior}

Figure 7 shows the cumulative weight loss of cast and solution treated $21-4-\mathrm{N}$ nitronic steel at $\left(1030^{\circ} \mathrm{C} / 150 \mathrm{~min}\right)$ and $\left(1080^{\circ} \mathrm{C} / 150 \mathrm{~min}\right)$ for the total test duration of 24 hours. The experimental results indicate that the erosion resistance of 21-4-N nitronic steel has improved significantly after solution 


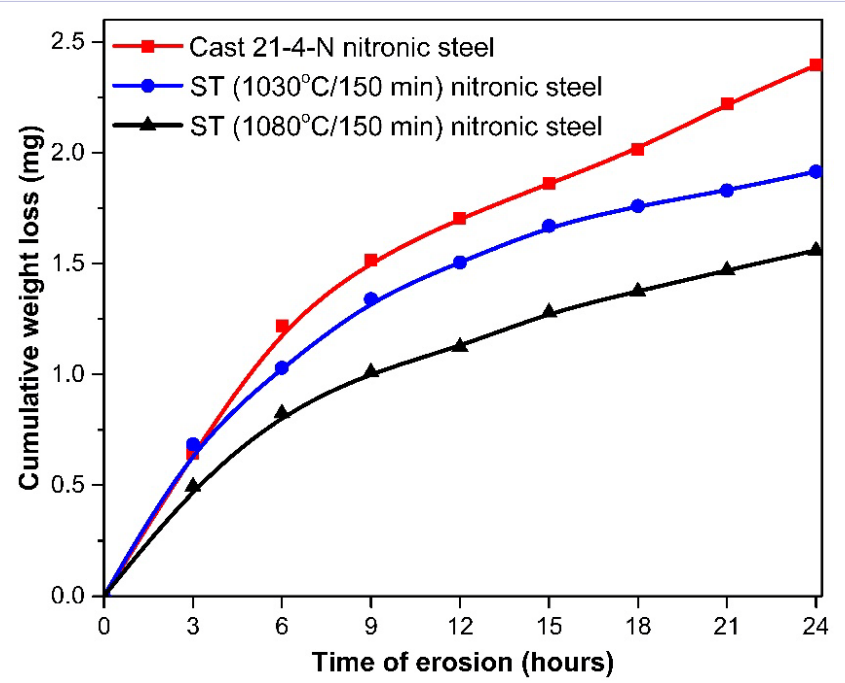

Figure 7: Cumulative weight loss of cast and solution treated 21-4-N nitronic steel at $\left(1030^{\circ} \mathrm{C} / 150 \mathrm{~min}\right)$ and $\left(1080^{\circ} \mathrm{C} / 150 \mathrm{~min}\right)$ with test duration.

annealing heat treatment. The erosion resistance of solution treated $21-4-\mathrm{N}$ nitronic steel at $\left(1030^{\circ} \mathrm{C} / 150 \mathrm{~min}\right)$ is almost $20 \%$ higher than that of the cast condition. The erosion resistance of solution treated $\left(1080^{\circ} \mathrm{C} / 150 \mathrm{~min}\right) 21-4-\mathrm{N}$ nitronic steel was also found to be better about $34.8 \%$ than erosion resistance of cast steel. During the beginning stage of erosion, cast 214-N nitronic steel could provide the resistance to erosion to a certain time. It is due to the presence of hard carbide, which hinders the penetration of sharp-edged sand particle on the steel surface. Generally, hardness is considered the most important property that affects the erosion resistance of material [15, 16]. However, the presence of unevenly distributed carbides produce high-stress concentration at carbide-matrix interface, and continuous impingement of sharp-edged sand particle on the surface resulted in carbide cracking and de-cohesion at carbide/austenite interface, which leads to mass removal [3, 7]. The increase in hardness alone is not sufficient to improve the erosion resistance. Ductility and impact energy also play a major role in improving the erosion resistance. Poor ductility leads to a tendency for localization of strains and development of cracks. Foley [17] proposed that ductility of the steels have a significant effect on erosion resistance, which increases with increasing in ductility. Hutching [18] also suggested that high hardness with some amount of ductility offer better erosion resistance. The erosion resistance of solution treated 21-4-N nitronic steel was improved with an increase in ductility. During the erosion, the erodent particles impact on the target surface. Therefore, impact energy absorption should play a significant role in erosion resistance. In the present study, the erosion resistance of the solution treated 21-4-N nitronic steel was increased with increase in the impact energy.

From the above discussion, it can be inferred that optimum hardness and increased ductility and impact energy after solution treatment plays a crucial role in improving the erosion resistance of cast 21-4-N nitronic steel.

\section{SEM Study of Eroded Samples}

SEM micrographs of the eroded surface of cast and solution treated $21-4-\mathrm{N}$ nitronic steel at $\left(1030^{\circ} \mathrm{C} / 150 \mathrm{~min}\right)$ and $\left(1080^{\circ} \mathrm{C} / 150 \mathrm{~min}\right)$ after 24 hours of erosion test are shown in Figure 8. It was observed that the craters formed during the erosion test were wider and deeper in the case of cast samples probably due to the removal of carbide particles. The plough was also seen in the eroded surface of cast 21-4-N nitronic steel. After the solution treatment of $21-4-\mathrm{N}$ nitronic steel at $1030^{\circ} \mathrm{C}$ for 150 min, the craters and plough were formed smaller probably due to the dissolution of carbides resulting in enhancement of ductility and impact energy of steel. Eroded surface of solution treated $\left(1080^{\circ} \mathrm{C} / 150 \mathrm{~min}\right) 21-4-\mathrm{N}$ nitronic steel shows that craters and plough were much smaller and less deep as compared to the cast and solution treated $\left(1030^{\circ} \mathrm{C} / 150 \mathrm{~min}\right) 21-4-\mathrm{N}$ nitronic steel eroded sample.

\section{Conclusions}

(i) The XRD analysis exhibits that most of the carbides were dissolved after the solution treatment of samples.

(ii) Solution treatment of the cast 21-4-N nitronic steel shows the significant changes in microstructure. Solution treated $\left(1080^{\circ} \mathrm{C} / 150 \mathrm{~min}\right) 21-4-\mathrm{N}$ nitronic steel exhibits a better dispersion of carbides in the austenitic matrix.

(iii)Tensile strength, ductility and impact energy increased after solution treatment while hardness was decreased as compared to cast sample.

(iv)The better slurry erosion resistance of solution treated $\left(1080^{\circ} \mathrm{C} / 150 \mathrm{~min}\right)$ could be attributed to the combination of optimum hardness coupled with high ductility and impact energy.
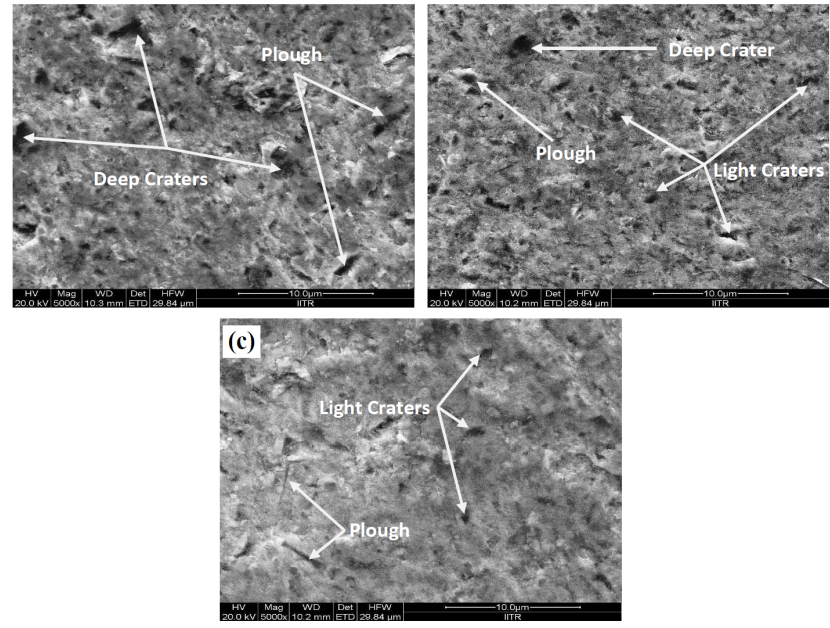

Figure 8: SEM micrographs of eroded surfaces of (a) cast 21-4-N nitronic steel; (b) solution treated $\left(1030^{\circ} \mathrm{C} / 150 \mathrm{~min}\right)$; and (c) solution treated $\left(1080^{\circ} \mathrm{C} / 150 \mathrm{~min}\right) 21-4-\mathrm{N}$ nitronic steel after $24 \mathrm{~h}$ of erosion test. 


\section{Acknowledgement}

The work is carried out under R\&D project entitled "Study of Metallurgical Aspects of Nitronic Steel for Underwater Part Applications" sponsored by Central Power Research Institute (CPRI), Bangalore (R\&D management code no.: 12/RSOP-GHMNIT-2011). Authors greatly acknowledge the funding and cooperation received from CPRI, Bangalore (India).

\section{References}

1. BSK Naidu. 1st International Conference on Silting Problems in Hydropower Plants. 1999;p.1-36.

2. DB Goel. Metallurgy of Erosion of Under Water Parts in Hydro Electric Projects, 3rd Int. Conf. on Silting problems in Hydropower Projects. 2008;p.1-12.

3. Avnish Kumar, Ashok Sharma, SK Goel. Effect of heat treatment on microstructure, mechanical properties and erosion resistance of cast 23-8-N nitronic steel. Mater Sci Eng A. 2015;637:(56-62). doi: 10.1016/j.msea.2015.04.031

4. Akhilesh K Chauhan, DB Goel and Satya Prakash. Erosion behaviour of hydro turbine steels. Bull Mater Sci. 2008;31(2):115-120.

5. Akhilesh K, Chauhan, DB Goel, S Prakash. Solid particle erosion behaviour of $13 \mathrm{Cr}-4 \mathrm{Ni}$ and $21 \mathrm{Cr}-4 \mathrm{Ni}-\mathrm{N}$ steels. J Alloys Compd. 2009;467(1-2):459-464. doi:10.1016/j.jallcom.2007.12.053.

6. Avnish Kumar, Ashok Sharma, SK Goel. Erosion behaviour of WC10Co-4Cr coating on 23-8-N nitronic steel by HVOF thermal spraying. Appl Surf Sci. 2016;370:418-426. doi: 10.1016/j.apsusc.2016.02.163.

7. Aniruddha A Gadhikar. Characterization Study of Steels for Erosion Resistant Applications. Ph.D. Thesis, MNIT Jaipur (India). 2011.

8. Dairo Hernan Mesa Grajales, Carlos Mario Garzon Ospina, Andre Paulo Tschiptschin. Mesoscale plasticity anisotropy at the earliest stages of cavitation-erosion damage of a high nitrogen austenitic stainless steel. Wear. 2009;267(1-4):99-103. doi:10.1016/j.wear.2008.12.079.
9. CM Hong, J Shi, LY Sheng, WC Cao, WJ Hui, H Dong. Effects of hotworking parameters on microstructural evolution of high nitrogen austenitic stainless steel. Mater Des. 2011;32(7):3711-3717. doi: 10.1016/j.matdes.2011.03.055.

10. Laura PMcCabe, Gordon A Sargent, Hans Conrad. Effect of microstructure on the erosion of steel by solid particles. Wear. 1985;105(3):257-277. doi:10.1016/0043-1648(85)90072-9

11.SG Sapate, AV Rama Rao. Effect of carbide volume fraction on erosive wear behaviour of hardfacing cast irons. Wear. 2004;256(7-8):774786. doi:10.1016/S0043-1648(03)00527-1

12. Cheng-Hsun Hsu, Sheng-Chien Chiu, Jung-Kai Lu, Yih-Hsun Shih. Effects of Eutectic Carbide Content on Erosion Behaviors in Ductile Cast Irons. Mater Trans. 2004;45(2):577-583. doi.org/10.2320/ matertrans. 45.577

13. KJ Kim, HU Hong, KS Min, SW Nam. Correlation between the carbide morphology and cavity nucleation in an austenitic stainless steels under creep-fatigue. Mater Sci Eng A. 2004;387-389:531-535. doi:10.1016/j.msea.2004.01.126

14. Joshua Salik, Donald H. Buckley. Effects of erodant particle shape and various heat treatments on erosion resistance of plain carbon steel. NASA Technical Paper. 1981;1755:1-8.

15.GR Desale, BK Gandhi, SC Jain. Slurry erosion of ductile materials under normal impact condition. Wear. 2008;264(3-4):322-330. doi:10.1016/j.wear.2007.03.022

16. Alan V Levy, Johnny Yan, Jennifer Patterson. Elevated temperature erosion of steels. Wear. 1986;108:43-60. doi:10.1016/00431648(86)90087-6

17.T. Foley, A. Levy, The erosion of heat-treated steels, Wear 1983;91 (1):45-64. doi:10.1016/0043-1648(83)90107-2

18. I.M. Hutchings, A model for the erosion of metals by spherical particles at normal incidence, Wear 1981;70 (3):269-281. doi:10.1016/00431648(81)90347-1 